\title{
ANTIDIABETIC EFFICACY OF ETHANOLIC EXTRACT OF HOLARRHENA ANTIDYSENTERICA SEEDS IN STREPTOZOTOCIN - INDUCED DIABETIC RATS AND ITS INFLUENCE ON CERTAIN B IOCHEMICAL PARAMETERS
}

\author{
*Keshri Umashanker Pd, Satish Chandra, Janardan Sharma \\ Department of Pharmacology, Rajendra Institute of Medical Sciences, Ranchi, 834009 \\ *Corresponding author's Email ID: uma.keshri@ rediffmail.com
}

Received 07 May 2012; Review Completed 27 May 2012; Accepted 25 June 2012, Available online 15 July 2012

\begin{abstract}
Holarrhena antidysenterica commonly known as kurci, kurchi or kutaj is being used from ancient time in the treatment of amoebiasis, chronic bronchitis, diabetes and locally for boils and ulcers. Present study was designed to evaluate the hypoglycemic effect of ethanolic extract of its seeds in streptozotocin - induced diabetic rats and its effect on serum cholesterol, trigly ceride, aspartate transaminase (AST), alanine transaminase (ALT), alkaline transferase (ALP), total protein, urea, creatinine and uric acid. Hy perglycemia was induced in overnight fasted albino rats by single intraperitoneal injection of streptozotocin (STZ) in $40 \mathrm{mg} / \mathrm{kg}$ body weight dose. The extract was administered orally at a dose of $300 \mathrm{and} 600 \mathrm{mg} / \mathrm{kg}$ body weight for 28 days. Oral glucose tolerance test done in normal rat. Glibenclamide was the reference drug used in the treatment. Significant antihyperglycemic effect was observed in ethanolic extract treated diabetic rats. There was gain in body weight and above mentioned biochemical parameter were reversed to near normal in ethanolic extract treated rats as compared to diabetic control rats. This is an indication of its potent antidiabetic effect.

Key words: Hy pogly cemic, streptozotocin, Holarrhena antidy senterica, diabetic
\end{abstract}

\section{INTRODUCTION}

Diabetes mellitus consists of a group of syndrome characterized by hyperglycemia, altered metabolis $\mathrm{m}$ of lipids, carbohydrates, and proteins; resulting from defects in insulin secretion, its action, or both ${ }^{1}$. It is a chronic metabolic disorder which affects a significant population world wide ${ }^{2}$. The total nu mber of people globally affected by diabetes was reported to be 171 million in 2000 and is projected to be 366 million by 2030 with a prevalence rate of 4.4 percent $^{3}$. Greatest number of cases being expected in China and India.

It is a major cause of morbidity and mortality. Present drugs which are used for the treatment of this disease are mainly insulin, sulphonylureas and biguanides. All these drugs are associated with adverse effect and not able to control metabolism adequately. Management of diabetes with agents devoid of any side effects is still a challenge to the medical system. There is growing interest in herbal remedies due to these reasons ${ }^{4}$.

From ancient time plant species are used in the treatment of various diseases. It is an important ingredient in traditional medicine. But yet only about five percent of the total plant species has been thoroughly tested for its safety and efficacy.

H. antidysenterica commonly known as kurci, kurchi or kutaj is one of the important medicinal herbs of the family Apocynaceae. Its seed is known as Indrayava or indrajab plays a major role as an ingredient in Ayurvedic prescriptions for flatulence, jaundice, piles and worms. Its bark is being used from ancient time in the treatment of amoebiasis, in chronic bronchitis and locally for boils and ulcers.
Recent study reflects the use of these traditional medicinal plants against malaria ${ }^{5}$, multiple antibiotic resistant enteropathogenic E. coli and in gut motility disorder ${ }^{6,7}$. There are few studies of different parts of this plant related to its hypoglycemic effect. Fifty percent ethanolic extract of fruit has shown hypoglycemic activity in rats ${ }^{8}$. Aqueous and alcoholic extract of its bark has reversed the hyperglycemic condition produced by streptozotocin injection ${ }^{9}$. Scientific data related to the antidiabetic efficacy of ethanolic extract of its seed in diabetic rats is lacking.

The purpose of this study was to investigate the efficacy of ethanolic extract of $\mathrm{H}$. antidysenterica seeds in STZ induced diabetic rats and evaluating its effect in blood cholesterol, total protein, alkaline phosphatase, aspartate trassaminase, alanine trassaminase, urea, creatinine and uric acid.

\section{MATERIALS AND METHODS}

H. antidysenterica seed were collected from the local market of Ranchi. Voucher specimens were deposited in the department of botany, Ranchi College Ranchi, of Ranchi University (voucher no. RIMS/15111/01). Taxonomist of this Department confirmed its identity.

\section{Plant extract preparation}

The seed were washed and dried in the shade. It was powdered in the grinder. Ethanolic extract (with 90\% ethanol) of it were made in the soxhlet apparatus. The extract was concentrated in evaporator under reduced presser at $40^{\circ} \mathrm{C}$. The extract was stored at $0-4^{\circ} \mathrm{C}$. 


\section{Experimental animals}

Permission for the study was taken from institutional animal ethics committee. Healthy albino rats of either sex of $2-2^{1 / 2}$ months old of body weight $125-150 \mathrm{~g}$ were housed in polypropylene cages at $25 \pm 2^{\circ} \mathrm{C}$ with light dark cycle of 12 hours. It was acclimatized for seven days. All animals were given standard rat feed and water ad libitum.

\section{Drugs and chemicals used}

Glibenclamide, streptozotocin and sodium citrate buffer were used in this study. The chemicals used in this study were of laboratory grade.

\section{Acute toxicity test}

Acute oral toxicity for the ethanolic extract of $\mathrm{H}$. antidysenterica seed (EHA) was carried out on the bas is of OECD guideline 425 . The dose of the drug was administered by calculating the weight; as $3000 \mathrm{mg} / \mathrm{kg}$ body weight. At first a single animal was tested. It was observed carefully to watch mortality and toxicity for 24 hours. Thereafter four other animals were also given EHA according to their body weight subsequently. The animals were marked and housed individually in cages. Animal were watched for 14 days. No animal died in this period. Therefore, the LD50 is greater than $3000 \mathrm{mg} / \mathrm{kg}^{10}$.

\section{Oral glucose tolerance test}

Oral glucose tolerance test ${ }^{11}$ was done in overnight (18 hour) fasted rats. Rats were divided into four groups $(\mathrm{N}=6)$ and distilled water $(10 \mathrm{ml} / \mathrm{kg})$, EHA (300 and $600 \mathrm{mg} / \mathrm{kg} \mathrm{b}$. w.), glibenclamide $(5 \mathrm{mg} / \mathrm{kg})$ were administered with glucose $(2 \mathrm{~g} / \mathrm{kg}$ b.w). Blood was drown from the tip of the tail at $0,1 / 2,1$ and $2 \mathrm{hr}$. interval and blood glucose level was estimated with the help of glucometer using strip method (ascensia entrust,bayer pharma).

\section{Anti diabe tic study}

Diabetes was induced in overnight fasted rat by single intraperitoneal injection of freshly prepared streptozotocin (Sisco research laboratory) dissolved in $0.1 \mathrm{M}$ ice cold sodium citrate buffer of $\mathrm{pH} 4.4$ at a dose of $40 \mathrm{mg} / \mathrm{kg} \mathrm{b}$.w. Ten percent glucose solution were allowed to overcome the drug-induced hypoglycemia. 3rd day plas ma glucose level of each rat was determined for confirmation of diabetes. Rats with plasma glucose level above $300 \mathrm{mg} / \mathrm{dl}$ were considered as a diabetic and used subsequently for further study.

Rats were divided into four groups, each group having six animals. Group 1 served as diabetic control and received distilled water $10 \mathrm{ml} / \mathrm{kg}$ b.w. Group $2 \mathrm{nd}$ and 3rd received ethanolic extract of $\mathrm{H}$. antidysenterica at a dose of $300 \mathrm{mg} / \mathrm{kg}$ and $600 \mathrm{mg} / \mathrm{kg}$ b.w, p.o respectively. Group 4 received the standard drug glibenclamide $5 \mathrm{mg} / \mathrm{kg}$ p.o. Blood glucose were estimated before starting the treatment and weekly up to the 4th week. Blood cholesterol, triglyceride, aspartate transaminase, alanine transaminase, alkaline phosphatase, total protein, urea, creatinine and uric acid were determined at the end of the experiment.

The drug was given once daily after determining hyperglycemia. Blood was drown in fasting condition from the tip of the tail and blood glucose level was estimated weekly till four week with the help of glucometer using strip method. At the end of the experiment (at four week) blood sample were taken by retro orbital sinus under ether anesthesia by bleeding method for measuring various biochemical parameter mentioned as above.

\section{STATISTICAL ANALYS IS}

Results were expressed as mean with standard deviation. The data were analyzed using analysis of variance (ANOVA). Group means were compared by Post Hoc test. Values were considered statistically significant with $\mathrm{p} \leq$ 0.05 .

\section{RES ULTS}

\section{Acute toxicity studies}

Acute toxicity studies revealed the nontoxic nature of the ethanolic extract of $\mathrm{H}$. antidysenterica. It did not produce changes in behavior, and general activity of the animal at $3000 \mathrm{mg} / \mathrm{kg}$ dose. All the animals were alive, healthy and active during the observation period. No death was observed at this dose. The fact that the LD50 of ethanolic extract of $\mathrm{H}$. antidysenterica is above $3000 \mathrm{mg} / \mathrm{kg}$ is an indication that the extract could be considered relatively safe, when given orally.

\section{Oral glucose tolerance test}

EHA significantly reduced plasma glucose levels $1 / 2 \mathrm{hr}$ after administration of glucose in euglycemic rats (Table $1)$.

Table 1: Effect of ethanolic extract of $\mathrm{H}$. antidysenterica seeds on oral glucos e tolerance test in normal rats

\begin{tabular}{|l|l|l|l|l|}
\hline Group & $0 \mathrm{hr} .(\mathrm{mg} / \mathrm{dl})$ & $1 / 2 \mathrm{hr} .(\mathrm{mg} / \mathrm{dl})$ & $1 \mathrm{hr} .(\mathrm{mg} / \mathrm{dl})$ & $2 \mathrm{hr} .(\mathrm{mg} / \mathrm{dl})$ \\
\hline Vehic le(Distilled water $10 \mathrm{ml} / \mathrm{kg})$ & $76.5 \pm 2.51$ & $92 \pm 2.83$ & $103 \pm 3.34$ & $87 \pm 0.89$ \\
\hline EHA(300mg/kg) & $78 \pm 3.22$ & $88.67 \pm 2.66$ & $96.33 \pm 3.83$ & $79.67 \pm 3.5$ \\
\hline EHA2 $(600 \mathrm{mg} / \mathrm{kg})$ & $80.16 \pm 2.99$ & $90.33 \pm 3.01$ & $99.17 \pm 2.04$ & $80 \pm 2.13$ \\
\hline GLB $(5 \mathrm{mg} / \mathrm{kg})$ & $81.33 \pm 2.34$ & $89 \pm 4.2$ & $93.83 \pm 5.08$ & $74 \pm 1.41$ \\
\hline
\end{tabular}

Values are mean $\pm S D$ of 6 rats in each group. $* P<0.05$ when compared with vehicle-treated group (Post hoc test).

\section{Changes in Body Weight}

Diabetic rats showed a decrease in body weight during the experimental period. $21.94 \%$ decrease was noted at the end of $4^{\text {th }}$ week. $H$. antidysenterica and glibenclamide treated diabetic group rat showed significant increase in weight.
Percentage increase in body weight in these $(\mathrm{H}$. antidysenterica 300 and $600 \mathrm{mg} / \mathrm{kg}$ b.w and glibenclamide) treated group were respectively $24.75,24.66$ and 27.51 in four weeks (Table 2). 
TABLE 2: Effect of ethanolic extract of $\mathrm{H}$. Antidysenterica seed on body weight of diabetic rats

\begin{tabular}{|l|l|l|l|l|l|}
\hline Group & 0 Week & 1 Week & 2 Week & 3 Week & 4 Week \\
\hline DC & $132.17 \pm 7.03$ & $127 \pm 7.03$ & $120.83 \pm 6.98$ & $111.83 \pm 5.83$ & $103.17 \pm 3.97$ \\
\hline EHA1 & $136.67 \pm 5.20$ & $143.67 \pm 6.65$ & $151.5 \pm 5.47$ & $159.5 \pm 3.73$ & $170.5 \pm 2.51$ \\
\hline EHA2 & $133.67 \pm 7.08$ & $143.67 \pm 6.65$ & $153 \pm 6.20$ & $161.33 \pm 5.57$ & $166.83 \pm 3.82$ \\
\hline GLB & $131.5 \pm 7.04$ & $138.5 \pm 7.42$ & $146.83 \pm 7.76$ & $153.5 \pm 10.25$ & $167.67 \pm 7.23$ \\
\hline
\end{tabular}

Mean body weight (g) ofdiabetic contwl (DC), ethanolic extract of H.antidysenterica seeds 300 and $600 \mathrm{mg} / \mathrm{kg}(\mathrm{EHAl} \&$ EHA2) and glibenclamide

$5 \mathrm{mg} / \mathrm{kg}(\mathrm{GLB})$ treated group albino rats during the experimental period. Values are mean $\pm S D$ of 6 rats in each group. *P<0.001 when compared with diabetic-control group (Post hoc test).

\section{Blood glucose le vel}

After streptozotocin injection all the rats developed diabetes and blood glucose level was at about $330 \mathrm{mg} / \mathrm{dl}$. Significant reduction $(\mathrm{P}<0.05)$ in blood glucose levels was observed weekly in EHA treated diabetic rats (in a dose of 300 and $600 \mathrm{mg} / \mathrm{kg}$ ) (Table 3). The decrease in blood glucose level in EHA treated group was less in comparis on to glibenclamide treated rats.

Table 3: Effect of ethanolic extract of H.antidysenterica seeds on STZ induced diabetic rats

\begin{tabular}{|l|l|l|l|l|l|}
\hline Group & 0 days & 7 days & 14 days & 21 days & 28 days \\
\hline Diabetic Control & $329.5 \pm 13.46$ & $334.33 \pm 6.62$ & $327.33 \pm 5.28$ & $327.5 \pm 10.82$ & $334.5 \pm 7.09$ \\
\hline EHA $_{1}$ treated & $329.33 \pm 8.76$ & $210.5 \pm 28.82$ & $179 \pm 10.20$ & $152.67 \pm 10.5$ & $133.67 \pm 6.71$ \\
\hline EHA $_{2}$ treated & $328.33 \pm 8.74$ & $244.83 \pm 11.2$ & $171 \pm 9.36$ & $139.5 \pm 20.96$ & $133 \pm 3.35$ \\
\hline GLB Treated & $332.83 \pm 6.01$ & $231.17 \pm 8.99$ & $163.83 \pm 16.15$ & $119.67 \pm 11.81$ & $88.67 \pm 2.16$ \\
\hline
\end{tabular}

Mean fasting blood glucose level (mg/dl) of diabetic control, ethanolic extract 300 and $600 \mathrm{mg} / \mathrm{kg}\left(\mathrm{EH} \mathrm{A}_{1} \& \mathrm{EH} \mathrm{A}_{2}\right)$ and glibenclamide $5 \mathrm{mg} / \mathrm{kg}(\mathrm{GLB})$ treated group albino rats during the experimental period. Values are mean $\pm S D, n=6$ in each group. $* P<0.001$ when compared with diabetic control rats (Post Hoc test).

\section{Effect on bi ochemical parameters}

Administration of Ethanolic extract of $\mathrm{H}$. antidysenterica in 300 , and $600 \mathrm{mg} / \mathrm{kg}$ dose for 4 weeks significantly decreased the total cholesterol $(\mathrm{P}<0.001)$ and trig lyceride ( $p<0.001)$ level in albino rats in comparison to diabetic control rats [Table 4].
A significant decrease in AST $(\mathrm{P}<0.05)$, ALT $(\mathrm{P}<$ $0.001)$, urea $(\mathrm{P}<0.05)$, and serum creatinine $(\mathrm{P}<0.05)$ level was found in EHA (in both 300 and $600 \mathrm{mg} / \mathrm{kg}$ dose) treated diabetic rats. Total plasma protein was significantly maintained in EHA treated rat.

Table 4: The effect of the ethanolic extract of H.antidysenterica seed on biomedical parameters

\begin{tabular}{|l|l|l|l|l|}
\hline & DC & EHA1 & EHA2 & GLB \\
\hline Cholesterol(mg/dl) & $140 \pm 3.41$ & $84 \pm 1.41^{*}$ & $82 \pm 2^{*}$ & $87 \pm 3.74$ \\
\hline Trig lyceride(mg/dl) & $182.50 \pm 4.23$ & $140 \pm 6.23^{*}$ & $136.83 \pm 5.67^{*}$ & $100 \pm 2.53$ \\
\hline AST(U/L) & $65.33 \pm 3.78$ & $45 \pm 2.28^{*}$ & $46 \pm 2.9$ & $43 \pm 2.37$ \\
\hline ALT(U/L) & $49 \pm 5.44$ & $43 \pm 2.1^{\circ}$ & $47 \pm 3.46$ & $39 \pm 2$ \\
\hline ALK(U/L) & $188.5 \pm 5.13$ & $167.83 \pm 4.9^{*}$ & $172.50 \pm 4.2^{*}$ & $166 \pm 3.95$ \\
\hline Total protein(mg/dl) & $4.4 \pm 0.28$ & $7.90 \pm 0.01^{\circ}$ & $8.2 \pm 0.05^{*}$ & $7.83 \pm 0.02$ \\
\hline Blood urea(mg/dl) & $0.48 \pm 0.02$ & $0.35 \pm 0.05$ & $0.38 \pm 0.08^{*}$ & $0.32 \pm 0.12$ \\
\hline Creatinine(mg/dl) & $2.91 \pm 0.16$ & $2.32 \pm 0.29$ & $2.48 \pm 0.19^{\circ}$ & $2.28 \pm 0.29$ \\
\hline Uric acid(mg/dl) & $2.48 \pm 0.19$ & $2.55 \pm 0.15$ & $2.32 \pm 0.29$ & $2.28 \pm 0.29$ \\
\hline
\end{tabular}

The effect of the ethanolic extract of H.antidysenterica seed on biochemical parameters of diabetic control (DC), ethanolic extract EHA 300 and $600 \mathrm{mg} / \mathrm{kg}(\mathrm{EHA1} \& \mathrm{EHA2})$ and glibenclamide $5 \mathrm{mg} / \mathrm{kg}(\mathrm{GLB})$ treated group albino rats during the experimental period. Data are expressed as mean $\pm S D .(N=6) . * P<0.001,{ }^{\circ} P<0.05$ when compared to diabetic control rats.

\section{DISCUSS ION}

In glucose tolerance test a significant reduction in plasma glucose levels was found in EHA treated euglyce mic rat when it was compared to normal control rats. It is probably due to its antihyperglycemic effect by retarding the carbohydrate absorption from intestine through the inhibitionin in $\alpha$-glucosidase activity. ${ }^{12}$

This study shows the efficacy of EHA seed in streptozotocin induced diabetic rats. Semiliar results of the methanolic extract of this plant seeds were reported by mana et $a l^{13}$. STZ caused the destruction of pancreatic $\beta$ cells in albino rats. Consequences to it animals developed marked hyperglycemia. Over production of glucose and decreased utilization by the tissues is the fundamental basis of hyperglycemia in diabetes mellitus. The possible hypoglycemic activity by EHA may be through potentiating action on $\beta$ cell of islets or stimulation of blood glucose uptake by peripheral tissue or/and inhibition of endogenous glucose production or activation of gluconeogenes is in liver and muscles ${ }^{14}$.

Decrease in body weight in streptozotocin induced diabetic rats and weight gain in EHA treated group (table 2) is due to loss of tissue protein ${ }^{15}$ and muscle wasting in the former and having beneficial effect in preventing loss of body weight and in catabolic process in EHA treated groups. 
Significant increase in weight in EHA treated group of albino rats in comparis on to vehicle treated diabetic rats indicating that ethanolic extract of $\mathrm{H}$. antidysenterica had beneficial effect in preventing loss of body weight of diabetic rats.

Insulin deficiency leads to various metabolic abnormalities in animals ${ }^{16,17}$. Increased ALT, AST, alkaline phosphates, serum cholesterol, serum trig lyceride and decreased total protein are indication of these abnormalities. Restoration of the level of biochemical enzy mes in $\mathrm{H}$. antidysenterica and glibenclamide treated albino rats are indication of better control of blood sugar level in this group.

\section{REFERENCES}

1. Scoppola A, Montecchi FR, Menzinger G, Lala A. Urinary mevalonate excretion rate in type 2 diabetes; Role of metabolic control. Atherosclerosis 2001; 156(2):357.

2. Wild S, Roglic G, Green A, Sicree R, King H. Global prevalence of diabetes. Diabetes care 2004;27(5):10471053.

3. King H, Aubert RE, Herman WH. Global burden of diabetes, 1995-2025: prevalence, numerical estimates, and projections. Diabetes care 1998;21(9):1414-1431.

4. Holman RR, Turner RC. Oral agents and insulin in the treatment of NIDDM. In: Pickup J, Williams G, editors. Textbook of Diabetes. Oxford: Blackwell; 1991. p. 467-469.

5. Verma G, Dua VK, Agarwal DD, Atul PK. Anti-malarial activity of Holarrhena antidy senterica and Viola canescens, plants traditionally used against malaria in the Garhwal region of north-west Himalay a. Malar J 2011;10:20

6. Kavitha D, Shilpa PN, Devaraj SN. Antibacterial and antidiarrhoeal effects of alkaloids of Holarrhena antidysenterica WALL. Indian J Exp Biol 2004;42(6):589594

7. Gilani AH, Khan A, Khan AU, Bashir S, Rehman NU, Mandukhail SU. Pharmacological basis for the medicinal use of Holarrhena antidy senterica in gut motility disorders. Pharm Biol 2010;48:1240-1246.

8. Dhar ML, Dhar MM, Dhawan BN, Mehrotra BN, Ray C. Screening of Indian plants for biological activity: I. Indian J Exp Biol 1968;6(4):232-247.

9. Dama GY, Rao MEB. Anti-diabetic activity of holorrhena antidy sentrica (linn) wall, Bark on streptozotocin induced

\section{CONCLUS ION}

The ethanolic extract of $H$. antidysenterica seed has antihyperglycemic activity as it lowers serum glucose level in diabetic albino rats and significantly increases glucose tolerance. It prevents weight loss in diabetic rats and corrects altered biochemical parameters e.g. serum cholesterol, triglyceride, aspartate transaminase, alanine transaminase, alkaline transferase, total protein, urea, creatinine and uric acid to near normal physiological range. This is an indication of its better metabolic control and potent antidiabetic property. Hence, further studies are required to know the exact mechanis $m$ of action and compound responsible for antidiabetic effect.

diabetic rats. International journal of intuitional pharmacy and life sciences 2011;1(2):24-38.

10. OECD guideline for the testing of chemicals (Acute oral toxicity-up and down procedure). Cited $2008 \mathrm{Mar}$ 20]; Available from:http://www.oecd.org.

11. Bonner-Weir S. Morphological evidence of pancreatic polarity of beta cells within islets of langerhans. Diabetes 1988;37(5):616-621. [PUBMED]

12. Ali KM, Chatterjee K, De D, Jana K, Bera TK, Ghosh D. Inhibitory effect of hydro-methanolic extract of seed of Holarrhena antidysenterica on alpha-glucosidase activity and postprandial blood glucose level in normoglycemic rat. J Ethnopharmacol 2011;135(1):194-196.

13. Mana S, Singhal S, Sharma NK,Singh D. Hypoglycemic Effect of Holarrhena antidysenterica Seeds on Streptozotocin induced Diabetic Rats. International Journal of PharmTech Research 2010;2(2):1325-1329.

14. Burcelin R, Eddouks M, Maury J, Kande J, Assan R, Girard J. Excessive glucose production rather than insulin resistance accounts for hypoglycemia in recent onset diabetic rats. Diabetolo gia 1995;38:283-290.

15. Chatterjea MN, Shinde R. Diabetes mellitus. In: Text Book of Medical Biochemistry. New Delhi: Jaypee Brother Medical Publisher; 2002.p. 317.

16. Nikkilä EA, Kekki M. Plasma trigly ceride transport kinetics in diabetes mellitus. Metabolism. 1973 ;22(1):1-22.

17. Shanmugasundaram KR, Panneerselvam C, Samudram P, Shanmugasundaram ER. Enzyme changes and glucose utilization in diabetic rabbits: The effect of Gymnema sylvestrae R Br. J Ethnopharmacol 1983;7(2):205-234. 